\title{
Liquid Biopsies for Cancer: Coming to a Patient near You
}

\author{
Nithya Krishnamurthy *, Emily Spencer, Ali Torkamani and Laura Nicholson \\ Scripps Translational Science Institute/The Scripps Research Institute, 3344 North Torrey Pines Court, Suite 300, \\ La Jolla, CA 92037, USA; spencer.emily@scrippshealth.org (E.S.); atorkama@scripps.edu (A.T.); \\ nicholson.laura@scrippshealth.org (L.N.) \\ * Correspondence: nithyamurthy9@gmail.com; Tel.: +1-858-554-5708; Fax: +1-858-546-9273
}

Academic Editor: Ryou-u Takahashi

Received: 13 October 2016; Accepted: 18 December 2016; Published: 4 January 2017

\begin{abstract}
The use of circulating tumor DNA (ctDNA) as a novel and non-invasive test for the diagnosis and surveillance of cancer is a rapidly growing area of interest, with sequencing of ctDNA acting as a potential surrogate for tissue biopsy. Circulating tumor DNA has been detected incidentally during noninvasive prenatal testing and additionally in more than $75 \%$ of known cancer patients participating in ctDNA studies evaluating its sensitivity. In the setting of mutation-based targeted tumor therapy, it shows a concordance rate $>80 \%$ when compared with gold-standard tissue biopsies. Through ctDNA detection and sequencing, a simple blood test becomes a liquid biopsy for cancer, surveying a patient's entire circulation with the goal of early detection, prognostic information, personalized therapy options, and tracking for recurrence or resistance, all with fewer or no tissue biopsies. Given the recent first-ever FDA approval of a liquid biopsy, it is important for clinicians to be aware of the rapid advancements likely to bring these tests into our practices soon. Here we review the biology, clinical implications, and recent advances in circulating tumor DNA analysis.
\end{abstract}

Keywords: cancer surveillance; genomics; personalized medicine; liquid biopsy

\section{Introduction}

DNA molecules circulating freely in human plasma, outside of cells, were first described in 1948, with practical clinical use beginning a half century later: hypothesizing that fetuses release DNA into mothers' blood, Lo et al. demonstrated in 1997 that women who carried male fetuses had Y chromosomal DNA in their plasma [1,2]. This research transformed prenatal screening, leading to an early gestation blood test for fetal gender and chromosomal abnormalities without any intrauterine disturbance [3].

Since the rapid adoption of circulating DNA-based prenatal testing and its unanticipated detection of malignancies in a small number of pregnant women, the use of circulating cell-free DNA to diagnose cancer has been a rapidly growing area of interest [4]. This circulating tumor DNA (ctDNA) had first been described in 1977 and has since been confirmed to contain the hallmark mutations of cancerous cells $[5,6]$. Early studies demonstrated a quantitative correlation between the amount of ctDNA and a patient's tumor burden [7]. Unfortunately, detection of ctDNA remained challenged by its presence in relatively low quantities, rendering it unproductive in early-stage cancer patients [8]. There are several available techniques to detect ctDNA including BEAMing, digital PCR, and next generation sequencing. Recently, however, advances in high-throughput sequencing and sophisticated computational methods as well as novel allele-specific qPCR have greatly improved the ability to detect and characterize ctDNA, with new techniques able to discover single-point mutations and track multiple genes of interest with increasing sensitivity [7,9-11]. 
Circulating tumor DNA has the potential to be a novel, non-invasive biomarker that promotes early detection at a more treatable stage, reduces the necessity of tissue biopsies, and reveals the emergence of resistance to treatment, thereby increasing the efficacy of targeted therapy. For cancers that are often detected at a late stage, including lung, pancreatic, and ovarian, a high-sensitivity ctDNA assay could function as a vastly improved screening test to detect typically terminal malignancy at an earlier, potentially curable stage. With temporal monitoring, this "liquid biopsy" shows great promise in monitoring cancer progression in real time, avoiding the significant morbidity and cost of repeat tissue biopsies.

\section{Biology of ctDNA}

The presence of cell-free DNA in the blood is well established. Fragments of DNA are constantly shed into the bloodstream during cell death, but the levels of cell-free DNA are kept relatively low due to the rapid clearance by the liver, kidney, and spleen. In general, patients with cancer have significantly higher levels of cell-free DNA as compared to healthy individuals because tumors tend to have elevated cell turnover rates and a large number of necrotic cells relative to normal tissue [12]. The median circulating plasma DNA concentration in patients with solid tumors has been noted to be three-fold higher than in healthy volunteers. Typically, dead and dying cells are cleared by filtering phagocytes, but this process does not happen efficiently for malignant cells, leading to the release of tumor DNA into the bloodstream. The rate of shedding of ctDNA into circulation is also dependent upon the location, size, and vascularity of the tumor, leading to variability in levels across patients [13]. Overall, the relative levels of ctDNA within a patient have been demonstrated to correlate with tumor burden, increasing as a tumor enlarges and decreasing with response to therapy. In colon cancer patients, for example, a tumor size of $100 \mathrm{~g}\left(\approx 3 \times 10^{10}\right.$ neoplastic cells) contributes to about $3.3 \%$ of the circulating DNA passed into circulation on a daily basis, whereas a much smaller proportion $(<1 \%)$ can be expected for smaller, less well-vascularized tumors [14,15]. Two primary explanations for the release of ctDNA into the bloodstream have been accepted to date-passive and active mechanisms. The release of nucleic acids from necrotic cells into the bloodstream is known as the passive mechanism, with macrophages and phagocytes playing an important role in this process. Fragments of cellular nucleic acid can also be actively released, potentially as a means to condition target cellular niches at distant locations throughout the body [16].

\subsection{Amount and Fragmentation of ctDNA}

The fragmentation pattern of circulating tumor DNA also reflects tumor biology. In solid cancers, tumor necrosis creates a spectrum of DNA fragments with varied sizes, due to the random digestion by nucleases. This contrasts with apoptosis in normal tissue, which releases small, homogeneous DNA fragments. Jiang et al. used massively parallel sequencing to study the size profiles of plasma DNA samples at a single-base resolution in a genome-wide manner, demonstrating that populations of aberrantly short and long DNA molecules exist in the plasma of hepatocellular carcinoma patients [17]. Short, circulating DNA molecule abundance was elevated in the plasma of these patients relative to healthy individuals, and the relative abundance of short DNA fragments from particular genomic regions was indicative of tumor-associated copy number aberrations. Mouliere et al. demonstrated that the quantity of short, circulating DNA fragments $<100 \mathrm{bp}$ is directly correlated with ctDNA concentration. Optimal detection of circulating tumor DNA is obtained with amplicons $<100 \mathrm{bp}$, with $98 \%$ of human colorectal cancer tumor DNA fragments being $<409 \mathrm{bp}$, but with the proportion of tumor-derived DNA rapidly declining for fragments greater than 150 bp [18]. ctDNA size profiles also vary within cancer type and stage. For example, short DNA fragments are more frequent in metastatic cancers when compared with earlier stages in breast cancer [19]. Similarly, blood-based DNA integrity, defined as the relation of long to small fragments of cell-free circulating DNA, is also known to correlate with cancer progression. In a 2014 study by Leszinski et al., ctDNA analysis in the serum of patients with colorectal cancer, patients with benign gastrointestinal diseases, and 
healthy controls indicated that the DNA integrity index was significantly higher in patients with colorectal cancer when compared with healthy controls and with individuals with benign colorectal diseases ( $p=0.005$ and $p=0.006$, respectively) [20]. For these reasons, circulating DNA size profiling is being examined for inclusion in a screening blood test for cancer, as it distinguishes early from late malignancies [21]. Evaluating across a diverse set of tumor types, Bettegowda et al. demonstrated that tumor stage significantly correlated with the presence of ctDNA-with $47 \%$ of Stage 1, 55\% of Stage 2, $69 \%$ of Stage 3, and $82 \%$ of Stage 4 cancer patients harboring detectable levels of ctDNA.

\subsection{Methylation Profiling}

Detection of tumor-specific DNA methylation through a liquid biopsy is another feasible approach for the development of diagnostic tests for early-stage cancer. Differential methylation levels of three promoters, RASSF1A, CALCA, and EP300, in the cell-free plasma could detect ovarian cancer from healthy controls with a sensitivity of $90 \%$ and a specificity of $86.7 \%$ in a 30 -patient cohort study [22]. Similarly, Lange et al. performed studies on methylated sequences in colorectal cancer, which demonstrated that methylation of the promoter region of the thrombomodulin gene (THBD) could differentiate colorectal cancer and control blood samples with a sensitivity of $71 \%$ and a specificity of $80 \%$ [23]. Methylated GSTP1-free DNA was a marker of prognosis and response to therapy in castration-resistant prostate cancer (CRPC) with detectable methylated GSTP1 at baseline being an independent predictor of poorer overall survival and higher levels after the first cycle of chemotherapy predictive for progression measured by prostate specific antigen (PSA) [24]. Thus, methylation profiling of ctDNA provides another potential biomarker for cancer screening and surveillance. The ZNF154 CpG island is so frequently hyper-methylated in malignancy that it is being studied as a pan-cancer marker [25]. If cell-free DNA quantity, fragmentation, or methylation raises suspicion for occult malignancy, it may be further studied for ctDNA characteristics suggesting individual cancer types, as we explore below.

\section{Diagnosis, Liquid Biopsy}

The multiple-hit theory of cancer describes a series of genetic mutations-some due to exposures and many due to accumulated DNA replication errors during aging —until a combination occurs that leads to malignant cell growth. The so-called "tumor driver" hits include DNA regions that control cell division, accelerating growth promoters or blocking growth suppressors when mutated [26]. Sequencing tumor DNA provides a window into the unstable genome of the tumor itself, optimally revealing the one or more mutations contributing to unchecked growth [8]. While each tumor is therefore genetically unique, mutations in certain genes are characteristic of certain cancer types $[8,27]$. For example, mutated $B R A F$ is seen in melanomas, $A L K$ raises suspicion for lung cancer, and EGFR has been described in multiple cancer types including lung, colorectal, pancreatic, breast, and thyroid. A screening blood sample in the right clinical scenario and in high-risk patients could be further evaluated for genomic alterations typical of certain cancer(s), as part of the ensuing work-up to diagnose an occult malignancy.

In the opposite clinical situation, when a mass is present and tissue characterization is needed, circulating cell-free DNA can provide clues to etiology with the presence or absence of typical malignancy traits and/or driver mutations. This might be useful when more information is desired but direct biopsy is technically difficult, delayed by logistics, or inadvisable due to patient frailty. In studies pairing plasma and tumor tissue, there was $>80 \%$ concordance in tumor DNA aberrations, with some results suggesting that the blood sample provided a more complete tumor profile than the tissue biopsy (i.e., ctDNA contained all or most of the tumor tissue DNA changes plus additional mutations) due to heterogeneity within primary tumors and between metastatic sites $[8,28-31]$. This suggests that ctDNA already complements and might eventually supplant direct biopsy, with $>80 \%$ sensitivity and $98 \%-100 \%$ specificity achieved in recent reports, and detection techniques improving rapidly $[10,11,32]$. 


\subsection{Circulating Tumor DNA versus Tissue Biopsy}

The current gold standard for clinical and investigational tumor genome profiling is paired tumor tissue/normal tissue sequencing from biopsy. Sample processing for standard, required pathological assessment can sometimes leave a tumor biopsy with insufficient material for cancer genome sequencing. Furthermore, the fraction of tumor cells relative to normal cells in each biopsy is varied, again potentially resulting in insufficient material, in turn requiring repeat aspirates or biopsies, further increasing risk to the patient [33]. Sampling of a single tumor region at the time of biopsy further limits the comprehensiveness of cancer genome sequencing due to intratumor heterogeneity. This intratumoral and intermetastatic tumor heterogeneity potentially leads to an incomplete picture of the mutational profile of the malignancy overall and may lead to the absence of information that is crucial for planning of targeted therapy regimens [29].

Circulating tumor DNA, on the other hand, provides the same key genetic information as a tissue biopsy but with some clear advantages. First, it is a mixture of DNA derived from multiple cancer sites in a single individual, providing a more representative genome of the malignancy relative to a localized biopsy. For example, Perkins et al. performed a large concordance study of ctDNA versus tissue biopsy genomic profiling in patients with advanced cancers, revealing a strong concordance between tumor biopsy data and ctDNA data, and suggesting that discordance is likely the result of a lack of sensitivity from tissue biopsies. Overall, the concordance rate between tissue biopsy and circulating ctDNA mutations was $83.3 \%$ in metastases biopsies (18 samples total) and $78.5 \%$ in primary tumor biopsies ( 65 specimens total). Second, the bloodstream is a readily accessible and minimally invasive source of tumor DNA, allowing repeated and longitudinal profiling of a tumor genome, for a relatively safe route to dynamic monitoring of tumor burden, heterogeneity, and response or resistance to treatment [30].

\subsection{Circulating Tumor DNA versus Circulating Tumor Cells}

Circulating tumor cells (CTCs) are another avenue for the non-invasive and dynamic profiling of cancer with many of the same benefits as ctDNA profiling [13]. However, a major hurdle in CTC analysis is a limited presence in the bloodstream. CTCs constitute as few as one cell per $1 \times 10^{9}$ normal bloodstream cells in patients with metastatic cancer, making their detection and isolation for genomic profiling a major challenge [34]. While technology to capture and profile circulating tumor cells has advanced rapidly, the complexity and cost may limit clinical utility relative to ctDNA-based methods. Initial studies, such as that performed by Diaz et al., suggest that when both ctDNA and CTCs were present, ctDNA fragments outnumbered CTCs by 50 to 1 [8]. In a recent trial of lung cancer patients, ctDNA outperformed CTCs for detection of the KRAS mutation, revealing sensitivities of $96 \%$ and $52 \%$, respectively [35].

\subsection{Circulating Tumor DNA versus Cancer Antigens}

PSA, cancer antigen (CA) 19-9, carcinoembryonic antigen (CEA), and CA-125 are protein biomarkers currently used to help detect malignancy and assess a therapeutic response in prostate, pancreatic, gastrointestinal, and ovarian cancers, respectively. However, they have performed poorly as screening assays and are proving to be unreliable for tumor prognosis and treatment response monitoring. Recently, clinical studies have demonstrated the utility of ctDNA-based biomarkers relative to protein biomarkers. For example, Diehl et al. found the quantification of ctDNA mutants and the detection of their presence/absence in colon cancer patients after surgery and chemotherapy to be more clinically useful than the cancer embryonic antigen (CEA) test [15]. In a comparison of radiographic imaging with ctDNA and CA 15-3 in metastatic breast cancer patients, CA 15-3 levels were elevated ( $>32.4 \mathrm{U}$ per milliliter) in 71 of the 114 samples $(62 \%)$, while ctDNA was detectable in 94 of the 114 samples (82\%). Using a modified bootstrapping method, the study demonstrated improved sensitivity for cancer detection of ctDNA over CA 15-3: of $85 \%$ vs. 59\% [36]. 


\section{Personalized Cancer Treatment}

Personalized cancer therapy based on a tumor's unique genetic makeup is the crux of tumor genome sequencing and is already underway with drugs designed to interfere with the hyper-growth signals of specific driver mutations [22]. For example, trametinib in combination with dabrafenib has improved overall survival in patients with metastatic melanoma with BRAF V600E or V600K mutations, and erlotinib (Tarceva ${ }^{\circledR}$ ) has significantly improved survival in EGFR-aberrant non-small cell lung cancer patients, even at late stages of disease [37,38]. Defining these mutations through a ctDNA liquid biopsy holds particular promise for prescribing personalized tumor therapy in cases in which tumor heterogeneity might not be fully represented with tissue biopsy or when a specimen is insufficient for all testing desired [8]. "Companion diagnostic" liquid biopsies seek to address exactly this issue, searching the ctDNA for a mutation that has a currently available targeted treatment.

\subsection{Cancer Prognosis, Relapse, and Resistance}

The bloodstream is a readily accessible and minimally invasive source of ctDNA, allowing repeated and longitudinal profiling of a tumor genome for relatively safe monitoring of tumor burden and treatment response [28]. With its half-life of less than two hours, ctDNA is dynamic and can be used to discover changes in evolving tumor genomes in real time [39]. Anticipating treatment resistance before overt clinical failure can be especially useful for patients expected to live with cancer for years. As an example of this type of prognosis, a cohort of 55 early-stage, non-metastatic breast cancer patients underwent ctDNA testing pre- and post-operatively, their tumor DNA signature representing a personalized cancer marker [40]. Positive ctDNA assays post-operatively signaled minimal residual disease, and these patients were more than four times as likely to relapse as patients with undetectable post-surgery ctDNA. Serial ctDNA testing every six months further predicted recurrence, with $93 \%$ of women who converted to ctDNA+ developing relapse compared to only $10 \%$ of women who remained ctDNA - [40].

In other studies, ctDNA-based detection preceded the clinical detection of metastasis in $>80 \%$ of patients in whom ctDNA was tracked, with average lead times as high as 11 months, suggesting the potential for earlier, more targeted therapy adjustment before a decline in functional status [39,41]. Additionally, ctDNA has outperformed cancer antigens (CAs) for the detection of residual disease and recurrence. Diehl et al. found the characterization of ctDNA mutants and their presence/absence in colon cancer patients after surgery and chemotherapy to be more clinically useful than the cancer embryonic antigen (CEA) test [15]. Studies have similarly shown ctDNA to be detectible in radiologically- and biopsy-proven relapsed ovarian cancer patients whose pre-treatment positive CA-125 did not reemerge [42,43].

Mutation burden tends to increase with serial ctDNA testing and more closely matches the relapsed tumor biopsy DNA sequence than the pretreatment tumor sequence, suggesting it could be used to prescribe next-line directed therapy. KRAS mutations promote resistance to EGFR-targeted therapies, and recent studies of colorectal cancer patients demonstrated $92 \%$ sensitivity and $98 \%$ specificity of ctDNA for detecting the development of KRAS point mutations; MEK1 mutation emerged in serial testing of one patient who responded to second-line treatment with the MEK inhibitor, trametinib [44,45]. Thus, ctDNA profiling has clear potential not only for the prioritization of initial therapy but also for the detection of emerging resistance and suggestion of second line therapeutic(s) [46]. Table 1 summarizes studies of ctDNA detection in common cancers. 
Table 1. Common cancers with ctDNA detection.

\begin{tabular}{|c|c|c|}
\hline $\begin{array}{l}\text { Type of Cancer } \\
\text { with ctDNA } \\
\text { Detection }\end{array}$ & Results & References \\
\hline Breast cancer & $\begin{array}{l}\text { ctDNA-based detection preceded clinical detection of metastasis in } 86 \% \\
\text { of patients }\end{array}$ & [47] \\
\hline Breast cancer & $\begin{array}{l}55 \text { non-metastatic breast cancer patients on neo-adjuvant chemotherapy; } \\
\text { in the immediate post-operative period, } 19 \% \text { of available patients had } \\
\text { detectible ctDNA, representing minimal residual disease (MRD), and } \\
86 \% \text { of these women went on to relapse during the study period }\end{array}$ & {$[40,48]$} \\
\hline $\begin{array}{l}\text { Colorectal } \\
\text { cancer }\end{array}$ & $\begin{array}{l}\text { metastatic colorectal cancer demonstrated } 100 \% \text { diagnostic sensitivity } \\
\text { and specificity for mutant } B R A F \text { detection and } \\
92 \% \text { sensitivity } / 98 \% \text { specificity for seven tested } K R A S \text { point mutations }\end{array}$ & {$[41]$} \\
\hline Lung cancer & $\begin{array}{l}\text { With tumor tissue DNA used as a reference, ctDNA demonstrated } \\
\text { a specificity of } 86 \% \text { for PI3KCA exon } 9,88 \% \text { for EGFR exon } 19 \text {, and } \\
100 \% \text { for other measured amplicons, with an } 87 \%(62 \%-96 \%) \text { overall } \\
\text { average specificity. Certain PIK3CA and EGFR hot-spot mutations were } \\
\text { detected in ctDNA but not in the tissue DNA }\end{array}$ & [49] \\
\hline Prostate cancer & $\begin{array}{l}\text { Tumor DNA samples from the blood of } 97 \text { patients with } \\
\text { castration-resistant prostate cancer at different times during the course } \\
\text { of treatment with abiraterone revealed androgen receptor } \\
\text { amplifications were present from the beginning and correlated with } \\
\text { abiraterone resistance }\end{array}$ & {$[50,51]$} \\
\hline
\end{tabular}

\subsection{Alternative Liquid Biopsy Sources}

While circulating tumor DNA broadens cancer surveillance beyond a single biopsy, sampling of other body fluids potentially broadens detection even further. Central nervous system malignancies have been difficult to detect in the blood stream but are more readily detected in cerebrospinal fluid (CSF) [52]. Urine sampling adds depth and convenience: urine cell-free tumor DNA exceeds plasma sensitivity in studies of renal, bladder, and prostate cancer, but surprisingly also in some series of lung and colon cancers [53-55]. Additionally, tumor DNA has been detected in saliva, bronchoalveolar washings, pleural fluid, ascites, endocervical samplings, and stool [56-60]. From this, one can envision cell-free DNA diagnostics using the body fluid most proximate to a tumor site or even a pan-fluid screening assay, as test sensitivities continue to improve.

\subsection{Available Liquid Biopsy}

In June of 2016, Roche's ctDNA-based detection of EGFR mutations in lung cancer patients was the first liquid biopsy to garner FDA approval. It is a high-specificity companion diagnostic for erlotinib, obviating the need for EGFR tissue testing when this blood test is positive [61]. More of these companion diagnostic liquid biopsies are being developed and will dramatically increase targeted therapy eligibility for patients too sick to undergo biopsy, too far from surgical centers, or with tumors too difficult to access safely. In the cancer screening sphere, Pathway Genomics ${ }^{\circledR}$ released a white paper describing 96 common, "hotspot" tumor mutations covered by their newly available liquid biopsy, CancerIntercept ${ }^{\mathrm{TM}}$ Detect, though the FDA halted testing until validation studies are completed [62].

\section{Limitations}

The potential of a liquid biopsy in translational cancer research is clearly acknowledged and these assays have been implemented in the design of various clinical trials. However, for utilization of the liquid biopsy in a clinical setting, standardization of pre-analytical and analytical methodologies, such as blood collection, processing and storage, DNA extraction and quantification, and validation in large prospective clinical studies, is necessary. The control of different parameters in all steps-from 
blood drawing to ctDNA analysis-has a significant impact on the quality and accuracy of the data. The quantity of ctDNA is also a potential limitation, though new amplification technologies have begun to eliminate this concern [63]. Very low levels of mutated DNA can show as false-positive results, when the occasional DNA aberrancy does not represent a cancer clone, and as false-negative results when the level is below assay detection limits [64]. Clinical implementation of the liquid biopsy requires undertaking long-term studies with adequate sample sizes [8]. A recent evaluation into the feasibility and effectiveness of ctDNA in a large clinical study concluded that while mutation testing using plasma specimens to obtain ctDNA was attainable, it resulted in low sensitivity and a low positive predictive value [65]. The low sensitivity witnessed was most likely due to the diversity of settings in which the liquid biopsy was employed, and to the various in-house laboratory techniques used to test for the EGFR mutation.

\section{Conclusions}

Liquid biopsies will add a new dimension to the cancer screening and diagnosis role of the primary care physician prior to oncology referral, so it is important to understand the underlying biology and the clinical opportunity driving the rapid emergence of these tests. The minimally invasive nature of ctDNA profiling tests for malignancy without the delay, cost, and risk associated with tissue biopsy, potentially at a microscopic stage before radiologic detectability. For cancers often detected at a late stage, such as lung, pancreatic, and ovarian, a ctDNA assay could detect a typically terminal malignancy at an earlier, more treatable, even curable stage. Suboptimal sensitivities and the need to confirm the tissue of origin will limit liquid biopsy's complete replacement of tumor biopsy for some time; however, we have discovered that "gold standard" tissue biopsies were a more limited portrait of an individual cancer than previously assumed and that concomitant liquid biopsy may add valuable, lower-morbidity treatment options for our patients.

Liquid biopsies for ctDNA have additional applications during cancer treatment, with dynamic monitoring of therapy response, early detection of resistance, and knowledge of tumor recurrence even months before clinical relapse. This could bring cancer surveillance back to the general internist's practice, until a patient's personalized tumor marker reemerges or evolves during serial testing. Table 2 highlights potential uses for liquid biopsy.

Table 2. Potential uses of liquid biopsy.

\begin{tabular}{l}
\hline \multicolumn{1}{c}{ Potential Uses of Liquid Biopsy } \\
\hline Detection of cancers in high-risk population \\
Monitoring for minimal residual disease \\
Detection of metastases before radiological evidence \\
Detection of response to therapy \\
Choice of targeted agent \\
Detection of new driver mutations \\
\hline
\end{tabular}

With the FDA's approval of the first liquid biopsy, it is time to prepare for the clinical appearance of these new tests. Next, researchers are examining circulating RNA as a potentially improved cancer profile, and DNA methylation for its ability to signal other types of tissue damage such as the destruction of pancreatic islet cells in type 1 diabetes mellitus or oligodendrocytes in relapsing multiple sclerosis [66-68]. The minimally invasive nature of ctDNA profiling revolutionizes longitudinal monitoring without significant risk. The sensitivities and costs of these assays are improving at unprecedented rates with even newer technology to follow. The potential to design trials based on new driver mutations and the use of mutation-specific targeted agents across multiple cancer types should propel the use of liquid biopsy in the future. There are exciting new applications for liquid biopsy in the detection of circulating extracellular vesicles or exosomes secreted by cancer cells [69]. 
Continued analytical validation of ctDNA testing is key for establishing ctDNA-based assays as standard in clinical practice.

Acknowledgments: Research support was provided by NIH/NCATS CTSA Award UL1 TR001114—Scripps Translational Science Institute.

Author Contributions: N.K., E.S., A.T. and L.N. all contributed to the manuscript and have reviewed it.

Conflicts of Interest: Other than Torkamani, the authors have no conflicts of interest, financial or otherwise, to disclose. Torkamani has received financial compensation for consultative services provided to Human Longevity, Inc., which could be considered partially related to the subject matter here.

\section{References}

1. Lo, Y.D.; Corbetta, N.; Chamberlain, P.F.; Rai, V.; Sargent, I.L.; Redman, C.W.; Wainscoat, J.S. Presence of fetal DNA in maternal plasma and serum. Lancet 1997, 350, 485-487. [CrossRef]

2. Mandel, P.; Metais, P. The nucleic acids in blood plasma in humans. C. R. Seances Soc. Biol. Fil. 1948, 142, 241-243. [PubMed]

3. Chiu, R.W.; Lo, Y.M. Noninvasive prenatal diagnosis empowered by high-throughput sequencing. Prenat. Diagn. 2012, 32, 401-406. [CrossRef] [PubMed]

4. Bianchi, D.W.; Chudova, D.; Sehnert, A.J.; Bhatt, S.; Murray, K.; Prosen, T.L.; Garber, J.E.; Wilkins-Haug, L.; Vora, N.L.; Warsof, S.; et al. Noninvasive Prenatal Testing and Incidental Detection of Occult Maternal Malignancies. JAMA 2015, 314, 162-169. [CrossRef] [PubMed]

5. Leon, S.A.; Shapiro, B.; Sklaroff, D.M.; Yaros, M.J. Free DNA in the serum of cancer patients and the effect of therapy. Cancer Res. 1977, 37, 646-650. [PubMed]

6. Tada, M.; Omata, M.; Kawai, S.; Saisho, H.; Ohto, M.; Saiki, R.K.; Sninsky, J.J. Detection of ras gene mutations in pancreatic juice and peripheral blood of patients with pancreatic adenocarcinoma. Cancer Res. 1993, 53, 2472-2474. [PubMed]

7. Diehl, F.; Schmidt, K.; Choti, M.A.; Romans, K.; Goodman, S.; Li, M.; Thornton, K.; Agrawal, N.; Sokoll, L.; Szabo, S.A.; et al. Circulating mutant DNA to assess tumor dynamics. Nat. Med. 2008, 14, 985-990. [CrossRef] [PubMed]

8. Diaz, L.A., Jr.; Bardelli, A. Liquid biopsies: Genotyping circulating tumor DNA. J. Clin. Oncol. 2014, 32, 579-586. [CrossRef] [PubMed]

9. Stadler, J.; Eder, J.; Pratscher, B.; Brandt, S.; Schneller, D.; Müllegger, R.; Vogl, C.; Trautinger, F.; Brem, G.; Burgstaller, J.P. SNPase-ARMS qPCR: Ultrasensitive Mutation-Based Detection of Cell-Free Tumor DNA in Melanoma Patients. PLoS ONE 2015, 10, e0142273. [CrossRef] [PubMed]

10. Lanman, R.B.; Mortimer, S.A.; Zill, O.A.; Sebisanovic, D.; Lopez, R.; Blau, S.; Collisson, E.A.; Divers, S.G.; Hoon, D.S.; Kopetz, E.S.; et al. Analytical and Clinical Validation of a Digital Sequencing Panel for Quantitative, Highly Accurate Evaluation of Cell-Free Circulating Tumor DNA. PLoS ONE 2015, 10, e0140712. [CrossRef] [PubMed]

11. Newman, A.M.; Lovejoy, A.F.; Klass, D.M.; Kurtz, D.M.; Chabon, J.J.; Scherer, F.; Stehr, H.; Liu, C.L.; Bratman, S.V.; Say, C.; et al. Integrated digital error suppression for improved detection of circulating tumor DNA. Nat. Biotechnol. 2016, 34, 547-555. [CrossRef] [PubMed]

12. Jahr, S.; Hentze, H.; Englisch, S.; Hardt, D.; Fackelmayer, F.O.; Hesch, R.D.; Knippers, R. DNA fragments in the blood plasma of cancer patients: Quantitations and evidence for their origin from apoptotic and necrotic cells. Cancer Res. 2001, 61, 1659-1665. [PubMed]

13. Haber, D.A.; Velculescu, V.E. Blood-based analyses of cancer: Circulating tumor cells and circulating tumor DNA. Cancer Discov. 2014, 4, 650-661. [CrossRef] [PubMed]

14. Jung, K.; Fleischhacker, M.; Rabien, A. Cell-free DNA in the blood as a solid tumor biomarker-A critical appraisal of the literature. Clin. Chim. Acta 2010, 411, 1611-1624. [CrossRef] [PubMed]

15. Diehl, F.; Li, M.; Dressman, D.; He, Y.; Shen, D.; Szabo, S.; Diaz, L.A.; Goodman, S.N.; David, K.A.; Juhl, H.; et al. Detection and quantification of mutations in the plasma of patients with colorectal tumors. Proc. Natl. Acad. Sci. USA 2005, 102, 16368-16373. [CrossRef] [PubMed]

16. Stroun, M.; Lyautey, J.; Lederrey, C.; Olson-Sand, A.; Anker, P. About the possible origin and mechanism of circulating DNA apoptosis and active DNA release. Clin. Chim. Acta 2001, 313, 139-142. [CrossRef] 
17. Jiang, P.; Chan, C.W.; Chan, K.A.; Cheng, S.H.; Wong, J.; Wong, V.W.; Wong, G.L.; Chan, S.L.; Mok, T.S.; Chan, H.L.; et al. Lengthening and shortening of plasma DNA in hepatocellular carcinoma patients. Proc. Natl. Acad. Sci. USA 2015, 112, E1317-E1325. [CrossRef] [PubMed]

18. Mouliere, F.; Robert, B.; Peyrotte, E.A.; Del Rio, M.; Ychou, M.; Molina, F.; Gongora, C.; Thierry, A.R. High fragmentation characterizes tumour-derived circulating DNA. PLoS ONE 2011, 6, e23418. [CrossRef] [PubMed]

19. Madhavan, D.; Wallwiener, M.; Bents, K.; Zucknick, M.; Nees, J.; Schott, S.; Cuk, K.; Riethdorf, S.; Trumpp, A.; Pantel, K.; et al. Plasma DNA integrity as a biomarker for primary and metastatic breast cancer and potential marker for early diagnosis. Breast Cancer Res. Treat. 2014, 146, 163-174. [CrossRef] [PubMed]

20. Leszinski, G.; Lehner, J.; Gezer, U. Increased DNA integrity in colorectal cancer. In Vivo 2014, 28, $299-303$. [PubMed]

21. Bettegowda, C.; Sausen, M.; Leary, R.J.; Kinde, I.; Wang, Y.; Agrawal, N.; Bartlett, B.R.; Wang, H.; Luber, B.; Alani, R.M.; et al. Detection of circulating tumor DNA in early- and late-stage human malignancies. Sci. Transl. Med. 2014, 6, 224ra24. [CrossRef] [PubMed]

22. Liggett, T.E.; Melnikov, A.; Yi, Q.; Replogle, C.; Hu, W.; Rotmensch, J.; Kamat, A.; Sood, A.K.; Levenson, V. Distinctive DNA methylation patterns of cell-free plasma DNA in women with malignant ovarian tumors. Gynecol. Oncol. 2011, 120, 113-120. [CrossRef] [PubMed]

23. Lange, C.P.; Campan, M.; Hinoue, T.; Schmitz, R.F.; van der Meulen-de, A.E.; Slingerland, H.; Kok, P.J.; van Dijk, C.M.; Weisenberger, D.J.; Shen, H.; et al. Genome-scale discovery of DNA-methylation biomarkers for blood-based detection of colorectal cancer. PLoS ONE 2012, 7, e50266. [CrossRef] [PubMed]

24. Mahon, K.L.; Qu, W.; Devaney, J.; Paul, C.; Castillo, L.; Wykes, R.J.; Chatfield, M.D.; Boyer, M.J.; Stockler, M.R.; Marx, G.; et al. Methylated Glutathione S-transferase 1 (mGSTP1) is a potential plasma free DNA epigenetic marker of prognosis and response to chemotherapy in castrate-resistant prostate cancer. Br. J. Cancer 2014, 1119, 1802-1809. [CrossRef] [PubMed]

25. Margolin, G.; Petrykowska, H.M.; Jameel, N.; Bell, D.W.; Young, A.C.; Elnitski, L. Robust Detection of DNA Hypermethylation of ZNF154 as a Pan-Cancer Locus with in Silico Modeling for Blood-Based Diagnostic Development. J. Mol. Diagn. 2016, 18, 283-298. [CrossRef] [PubMed]

26. Knudson, A.G., Jr. Mutation and cancer: Statistical study of retinoblastoma. Proc. Natl. Acad. Sci. USA 1971, 68, 820-823. [CrossRef] [PubMed]

27. Abramson, R. Overview of Targeted Therapies for Cancer. My Cancer Genome, 2016. Available online: https:/ / www.mycancergenome.org/content/molecular-medicine/overview-of-targeted-therapies-forcancer/ (accessed on 23 July 2016).

28. Patel, K.M.; Tsui, D.W. The translational potential of circulating tumour DNA in oncology. Clin. Biochem. 2015, 48, 957-961. [CrossRef] [PubMed]

29. Gerlinger, M.; Rowan, A.J.; Horswell, S.; Larkin, J.; Endesfelder, D.; Gronroos, E.; Martinez, P.; Matthews, N.; Stewart, A.; Tarpey, P.; et al. Intratumor heterogeneity and branched evolution revealed by multiregion sequencing. N. Engl. J. Med. 2012, 366, 883-892. [CrossRef] [PubMed]

30. Perkins, G.; Yap, T.A.; Pope, L.; Cassidy, A.M.; Dukes, J.P.; Riisnaes, R.; Massard, C.; Cassier, P.A.; Miranda, S.; Clark, J.; et al. Multi-purpose utility of circulating plasma DNA testing in patients with advanced cancers. PLoS ONE 2012, 7, e47020. [CrossRef] [PubMed]

31. Couraud, S.; Vaca-Paniagua, F.; Villar, S.; Oliver, J.; Schuster, T.; Blanché, H.; Girard, N.; Trédaniel, J.; Guilleminault, L.; Gervais, R.; et al. Noninvasive diagnosis of actionable mutations by deep sequencing of circulating free DNA in lung cancer from never-smokers: A proof-of-concept study from BioCAST/IFCT-1002. Clin Cancer Res. 2014, 20, 4613-4624. [CrossRef] [PubMed]

32. Lebofsky, R.; Decraene, C.; Bernard, V.; Kamal, M.; Blin, A.; Leroy, Q.; Frio, T.R.; Pierron, G.; Callens, C.; Bieche, I.; et al. Circulating tumor DNA as a non-invasive substitute to metastasis biopsy for tumor genotyping and personalized medicine in a prospective trial across all tumor types. Mol. Oncol. 2015, 9, 783-790. [CrossRef] [PubMed]

33. Peppercorn, J. Toward improved understanding of the ethical and clinical issues surrounding mandatory research biopsies. J. Clin. Oncol. 2013, 31, 1-2. [CrossRef] [PubMed]

34. Heitzer, E.; Auer, M.; Ulz, P.; Geigl, J.B.; Speicher, M.R. Circulating tumor cells and DNA as liquid biopsies. Genome Med. 2013, 5, 73. [CrossRef] [PubMed] 
35. Freidin, M.B.; Freydina, D.V.; Leung, M.; Fernandez, A.M.; Nicholson, A.G.; Lim, E. Circulating Tumor DNA Outperforms Circulating Tumor Cells for KRAS Mutation Detection in Thoracic Malignancies. Clin. Chem. 2015, 61, 1299-1304. [CrossRef] [PubMed]

36. Shaw, J.A.; Stebbing, J. Circulating free DNA in the management of breast cancer. Ann. Transl. Med. 2014, 2, 3. [PubMed]

37. Robert, C.; Karaszewska, B.; Schachter, J.; Rutkowski, P.; Mackiewicz, A.; Stroiakovski, D.; Lichinitser, M.; Dummer, R.; Grange, F.; Mortier, L.; et al. Improved overall survival in melanoma with combined dabrafenib and trametinib. N. Engl. J. Med. 2015, 372, 30-39. [CrossRef] [PubMed]

38. Rosell, R.; Carcereny, E.; Gervais, R.; Vergnenegre, A.; Massuti, B.; Felip, E.; Palmero, R.; Garcia-Gomez, R.; Pallares, C.; Sanchez, J.M.; et al. Erlotinib versus standard chemotherapy as first-line treatment for European patients with advanced EGFR mutation-positive non-small-cell lung cancer [EURTAC]: A multicentre, open-label, randomised phase 3 trial. Lancet Oncol. 2012, 13, 239-246. [CrossRef]

39. Yong, E. Cancer biomarkers: Written in blood. Nature 2014, 511, 524-526. [CrossRef] [PubMed]

40. Garcia-Murillas, I.; Schiavon, G.; Weigelt, B.; Ng, C.; Hrebien, S.; Cutts, R.J.; Cheang, M.; Osin, P.; Nerurkar, A.; Kozarewa, I.; et al. Mutation tracking in circulating tumor DNA predicts relapse in early breast cancer. Sci. Transl. Med. 2015, 7, 302ra133. [CrossRef] [PubMed]

41. Spindler, K.L.; Pallisgaard, N.; Andersen, R.F.; Brandslund, I.; Jakobsen, A. Circulating free DNA as biomarker and source for mutation detection in metastatic colorectal cancer. PLOS ONE 2015, 10, e0108247. [CrossRef] [PubMed]

42. Martignetti, J.A.; Camacho-Vanegas, O.; Priedigkeit, N.; Camacho, C.; Pereira, E.; Lin, L.; Garnar-Wortzel, L.; Miller, D.; Losic, B.; Shah, H.; et al. Personalized ovarian cancer disease surveillance and detection of candidate therapeutic drug target in circulating tumor DNA. Neoplasia 2014, 16, 97-103. [CrossRef] [PubMed]

43. Menon, U.; Griffin, M.; Gentry-Maharaj, A. Ovarian cancer screening-Current status, future directions. Gynecol. Oncol. 2014, 132, 490-495. [CrossRef] [PubMed]

44. De Cuba, E.M.; Snaebjornsson, P.; Heideman, D.A.; van Grieken, N.C.; Bosch, L.J.; Fijneman, R.J.; Belt, E.; Bril, H.; Stockmann, H.B.; Hooijberg, E.; et al. Prognostic value of BRAF and KRAS mutation status in stage II and III microsatellite instable colon cancers. Int. J. Cancer 2016, 138, 1139-1145. [CrossRef] [PubMed]

45. Russo, M.; Siravegna, G.; Blaszkowsky, L.S.; Corti, G.; Crisafulli, G.; Ahronian, L.G.; Mussolin, B.; Kwak, E.L.; Buscarino, M.; Lazzari, L.; et al. Tumor Heterogeneity and Lesion-Specific Response to Targeted Therapy in Colorectal Cancer. Cancer Discov. 2016, 6, 147-153. [CrossRef] [PubMed]

46. Esposito, A.; Criscitiello, C.; Locatelli, M.; Milano, M.; Curigliano, G. Liquid biopsies for solid tumors: Understanding tumor heterogeneity and real time monitoring of early resistance to targeted therapies. Pharmacol. Ther. 2016, 157, 120-124. [CrossRef] [PubMed]

47. Dawson, S.J.; Tsui, D.W.; Murtaza, M.; Biggs, H.; Rueda, O.M.; Chin, S.F.; Dunning, M.J.; Gale, D.; Forshew, T.; Mahler-Araujo, B.; et al. Analysis of circulating tumor DNA to monitor metastatic breast cancer. N. Engl. J. Med. 2013, 368, 1199-1209. [CrossRef] [PubMed]

48. Olsson, E.; Winter, C.; George, A.; Chen, Y.; Howlin, J.; Tang, M.H.; Dahlgren, M.; Schulz, R.; Grabau, D.; van Westen, D.; et al. Serial monitoring of circulating tumor DNA in patients with primary breast cancer for detection of occult metastatic disease. EMBO Mol. Med. 2015, 7, 1034-1047. [CrossRef] [PubMed]

49. Sundaresan, T.K.; Sequist, L.V.; Heymach, J.V.; Riely, G.J.; Jänne, P.A.; Koch, W.H.; Sullivan, J.P.; Fox, D.B.; Maher, R.; Muzikansky, A.; et al. Detection of T790M, the acquired resistance EGFR mutation, by tumor biopsy versus noninvasive blood-based analyses. Clin. Cancer Res. 2016, 22, 1103-1110. [CrossRef] [PubMed]

50. Hovelson, D.H.; Tomlins, S.A. The Role of Next-Generation Sequencing in Castration-Resistant Prostate Cancer Treatment. Cancer J. 2016, 22, 357-361. [CrossRef] [PubMed]

51. Sidaway, P. Prostate cancer: Genetics of mCRPC tracked in ctDNA. Nat. Rev. Urol. 2016. [CrossRef] [PubMed]

52. Pan, W.; Gu, W.; Nagpal, S.; Gephart, M.H.; Quake, S.R. Brain tumor mutations detected in cerebral spinal fluid. Clin. Chem. 2015, 61, 514-522. [CrossRef] [PubMed]

53. Goessl, C.; Muller, M.; Straub, B.; Miller, K. DNA alterations in body fluids as molecular tumor markers for urological malignancies. Eur. Urol. 2002, 41, 668-676. [CrossRef]

54. Husain, H.; Kosco, K.; Guerrero, S.; Lu, T.T.; Vibat, C.R.T.; Erlander, M.G.; Melnikova, V. Detection of EGFR T790M mutation in urinary circulating tumor DNA from metastatic non-small cell lung cancer patients. Ann. Oncol. 2015, 26, i10. [CrossRef] 
55. Su, Y.H.; Wang, M.; Brenner, D.E.; Norton, P.A.; Block, T.M. Detection of mutated K-ras DNA in urine, plasma, and serum of patients with colorectal carcinoma or adenomatous polyps. Ann. N. Y. Acad. Sci. 2008, 1137, 197-206. [CrossRef] [PubMed]

56. Wang, Y.; Springer, S.; Mulvey, C.L.; Silliman, N.; Schaefer, J.; Sausen, M.; James, N.; Rettig, E.M.; Guo, T.; Pickering, C.R.; et al. Detection of somatic mutations and HPV in the saliva and plasma of patients with head and neck squamous cell carcinomas. Sci. Transl. Med. 2015, 7, 293ra104. [CrossRef] [PubMed]

57. Leslie, C.; Giardina, T.; Carrello, A.; Spagnolo, D.V.; Amanuel, B. Detection of EGFR mutational profile by direct dideoxy sequencing in cytology and non-cytology biopsy samples. Pathology 2014, 46, 283-288. [CrossRef] [PubMed]

58. Benlloch, S.; Martí-Ciriquián, J.L.; Galbis-Caravajal, J.M.; Martín, C.; Sánchez-Payá, J.; Rodríguez-Paniagua, J.M.; Romero, S.; Massutí, B. Cell-free DNA concentration in pleural fluid and serum: Quantitative approach and potential prognostic factor in patients with cancer and pleural effusions. Clin. Lung Cancer 2006, 8, 140-145. [CrossRef] [PubMed]

59. Garner, D. Clinical application of DNA ploidy to cervical cancer screening: A review. World J. Clin. Oncol. 2014, 55, 931-965. [CrossRef] [PubMed]

60. Zhang, H.; Qi, J.; Wu, Y.Q.; Zhang, P.; Jiang, J.; Wang, Q.X.; Zhu, Y.Q. Accuracy of early detection of colorectal tumours by stool methylation markers: A meta-analysis. World J. Gastroenterol. 2014, 20, 14040-14050. [CrossRef] [PubMed]

61. Uchida, J.; Kato, K.; Kukita, Y.; Kumagai, T.; Nishino, K.; Daga, H.; Nagatomo, I.; Inoue, T.; Kimura, M.; Oba, S.; et al. Diagnostic accuracy of noninvasive genotyping of EGFR in lung cancer patients by deep sequencing of plasma cell-free DNA. Clin. Chem. 2015, 61, 1191-1196. [CrossRef] [PubMed]

62. PathwayGenomics. Liquid Biopsy for the Detection and Monitoring of Cancer: Analysis of 96 Hotspot Mutations via Plasma Derived Circulating Tumor DNA. White Paper. Available online: https:/ /d2q8958pmybfsy.cloudfront.net/wp-content/uploads/2014/07/T-1032.001-CancerIntercept_ WhitePaper.pdf?280a6d2015 (accessed on 4 August 2016).

63. Newman, A.M.; Bratman, S.V.; To, J.; Wynne, J.F.; Eclov, N.C.W.; Modlin, L.A.; Liu, C.L.; Neal, J.W.; Wakelee, H.A.; Merritt, R.E.; et al. An ultrasensitive method for quantitating circulating tumor DNA with broad patient coverage. Nat. Med. 2014, 20, 548-554. [CrossRef] [PubMed]

64. Ilie, M.; Hofman, V.; Long, E.; Bordone, O.; Selva, E.; Washetine, K.; Marquette, C.H.; Hofman, P. Current challenges for detection of circulating tumor cells and cell-free circulating nucleic acids, and their characterization in non-small cell lung carcinoma patients. What is the best blood substrate for personalized medicine? Ann. Transl. Med. 2014, 2, 107. [PubMed]

65. Reck, M.; Hagiwara, K.; Han, B.; Tjulandin, S.; Grohe, C.; Yokoi, T.; Morabito, A.; McCormack, R.; Ratcliffe, M.; Normanno, N. 35O_PR Investigating the utility of circulating-free tumor DNA(ctDNA) in plasma for the detection of epidermal growth factor receptor(EGFR) mutation status in European and Japanese patients (PTS) with advanced non-small cell lung cancer(ANSCLC): Assess study. Ann. Oncol. 2015, 26, i58-i59.

66. Hou, W.; Bonkovsky, H.L. Non-coding RNAs in hepatitis C-induced hepatocellular carcinoma: Dysregulation and implications for early detection, diagnosis and therapy. World J. Gastroenterol. 2013, 19, 7836-7845. [CrossRef] [PubMed]

67. Kishikawa, T.; Otsuka, M.; Ohno, M.; Yoshikawa, T.; Takata, A.; Koike, K. Circulating RNAs as new biomarkers for detecting pancreatic cancer. World J. Gastroenterol. 2015, 21, 8527-8540. [CrossRef] [PubMed]

68. Lehmann, M.M.; Fischer, M.; Blees, J.; Zech, M.; Siegwolf, R.T.; Saurer, M. A novel methylation derivatization method for $\delta 18 \mathrm{O}$ analysis of individual carbohydrates by gas chromatography/pyrolysis-isotope ratio mass spectrometry. Rapid Commun. Mass Spectrom. 2016, 30, 221-229. [CrossRef] [PubMed]

69. Yoshioka, Y.; Kosaka, N.; Konishi, Y.; Ohta, H.; Okamoto, H.; Sonoda, H.; Nonaka, R.; Yamamoto, H.; Ishii, H.; Mori, M.; et al. Ultra-sensitive liquid biopsy of circulating extracellular vesicles using ExoScreen. Nat. Commun. 2014, 5, 3591. [CrossRef] [PubMed]

(c) 2017 by the authors; licensee MDPI, Basel, Switzerland. This article is an open access article distributed under the terms and conditions of the Creative Commons Attribution (CC-BY) license (http://creativecommons.org/licenses/by/4.0/). 